An Introduction to the Chemistry of the Hydrides By Dallas T. Hurd. Pp. $x+231$. (New York: John Wiley and Sons, Inc.; London: Chapman and Hall, Ltd., 1952.) 44s. net.

THE group of compounds known collectively as the hydrides includes examples of a very wide range of chemical bonds, and therein lies much of its fascination. Until recently, no great effort had been made to look at this group as a whole; indeed, no monograph has previously appeared covering the whole field, although several wellknown works dealing with small sections of the field have appeared. Dr. D. T. Hurd, who has himself made several important contributions to hydride chemistry, presents a comprehensive survey of the hydrides, including a considerable amount of descriptive and preparative chemistry.

Several chapters are devoted to a general consideration of the main types of hydride and such topics as chemical binding and acids and bases. Outside these general chapters the material is dealt with in groups, passing from the salt-like hydrides, through the hydrides of the non-metals to those of the transition elements and those of the copperand zinc-type elements. The book is likely to be of interest both to those who are engaged in research and to those who are teaching advanced inorganic chemistry. In particular, the inclusion of a brief but adequate consideration of the well-known hydrides along with the less well-known compounds is particularly valuable, as is much of the technical information on the production and uses of certain of the hydrides. Limited reference is made to the complex hydrides such as lithium aluminium hydride. A chapter is included to cover the nomenclature of the hydrides, and the appendix deals with several topics in a very brief and sketchy fashion, for example, the vacuum manipulation of volatile compounds and the toxicology of the hydrides.

The book is well prepared and presented and contains only a few minor mistakes.

\section{S. Payne}

\section{Removing the Causes of War}

By Dr. Kathleen Lonsdale. (Swarthmore Lecture, 1953.) Pp. ix +76. (London: George Allen and Unwin, Ltd., 1953.) Paper, 3s. 6d. net; cloth, 5s. net.

DROF. KATHLEEN LONSDALE'S Swarthmore

Lecture for 1953 is an attempt to analyse the causes of war and the ways in which they may be removed. Even when criticism is tempered by the qualification that her attempt is undertaken within the framework of Quaker ways of thinking and acting, the Lecture is nevertheless disappointing. Few readers will question that the wholesale conversion of the world to the Quaker doctrine of non-violence would lead to the elimination of war, even if causes of international dispute still remained. The Christian might accept the possibility of such a wholesale conversion as reasonable; but, in the meantime, it is asking rather much of the non-Christian world to rest hopes of the elimination of war upon such an assumption. Prof. Lonsdale's lecture is disappointing because she offers so few positive and constructive suggestions for the removal of the causes of war on which men and women of goodwill could co-operate further.

By and large, Prof. Lonsdale adds little to what had already found formal expression when the Kellogg Pact for the renunciation of war as a means of settling international disputes was signed, and when, in its various technical committees, the League of Nations was already demonstrating the practicability of international co-operation, given the common purpose. On technical assistance to the underdeveloped areas, she writes with realism; but there is slender guidance in these pages for the reader who looks for a clue to the resolution of the problems of power and responsibility, loyalty, law and order and their ultimate sanction in a world at so many differing levels of idealism, moral standards and physical needs.

R. B.

\section{The Physical Chemistry of Proteins}

Discussions of the Faraday Society, No. 13, 1953. Pp. $288+4$ plates. (London : The Faraday Society, 1953.) 35s. net.

7 HIS volume contains the published proceedings of the symposium on "The Physical Chemistry of Proteins" which was held during August 1952 in Cambridge under the auspices of the Faraday Society. In addition to the papers, it contains the Sixth Spiers Memorial Lecture on "The Molecular Shapes of certain Proteins and some of their Interactions with other Substances", by Prof. J. T. Edsall, and contributions to the general discussion. The papers are divided into five sections : experimental techniques (recent developments); low molecular weight proteins; high molecular weight systems ; protein interactions; and conjugated proteins (nucleo- and muco-proteins). Most of the papers contain accounts of original experimental investigations, though useful theoretical (for example, on muscle action and antigen - antibody reactions) and review articles (for example, on conjugated proteins) are presented. The volume covers the subject very broadly and should give a useful impression of its state of development.

\section{The Shoreshooter}

By Richard Arnold. Pp. $143+9$ plates. (London : Seeley Service and Co., Ltd., 1953.) 12s. 6d. net.

T $N$ days not so long gone every naturalist used a gun in the course of his studies of birds and mammals. To-day he more commonly uses fieldglasses, observation having largely taken the place of shooting. Books about bird-watching are legion; but books about the shotgun are not nearly so many, hence Richard Arnold's volume, "The Shoreshooter", will be helpful to those desirous of using gun and cartridges in the neighbourhood of salt water. The author has set out to provide information "on the practical side of fowling, dealing with practical problems", for the man who desires sport but must consider the financial aspect. Nevertheless, he turns to the things the fowler sees, and appreciates "the glorious dawns, the perfect 'fowler's moons" ", and his "thrills to the calls of the wild geese".

Mr. Arnold deals with guns and cartridges, clothing and equipment, wild geese shooting, the shooting of ducks and waders, and has some excellent notes on waterfowl, useful alike to the man with and without a gun. The person who prefers binoculars to a gun will also find much of interest in the chapter on decoys, dogs, cooking and the law.

In conclusion, a few words must be spared for the fine illustrations from photographs by Eric Hosking. Plate 3, a crowd of dunlin on the shore, is a picture to make all wild-life- photographers envious.

Frances Prtt 